
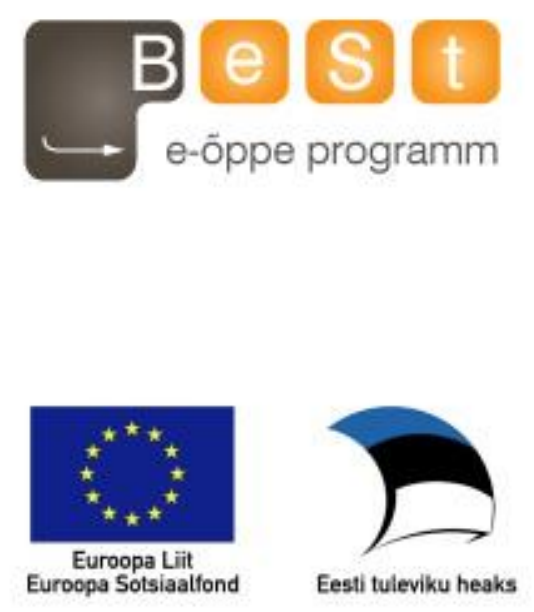

E-kursuse "Loss, grief and bereavement" materjalid

Tartu Ülikoolis õpetatava aine P2AV.TK.330 „Loss, grief and bereavement““ juurde

Aine maht 4 EAP

Karmel Tall (Tartu Ülikool), 2010 


\section{History of Thanatology}

The science dealing with death is known as thanatology (Greek thanatos, death, and logos, word or science). The complexity of this discipline is partly suggested by the following facts. It seems that, when social integration is dominant and social values are accepted automatically, the awareness of death is limited. But when social disorganization is prevalent and individualism intensifies, the consciousness of death becomes stronger. The latter have occurred in Hellenistic times, during the early Renaissance, and in the 20th century. The study of death has also been more intensive and extensive during these three periods.

Such research, however, has usually been neglected by great philosophers. Baruch Spinoza (1632-1677), for instance, has only given us one single sentence on death, unlike men of letters, who have written much more concerning this subject. Perhaps, philosophers have been neglectful simply because they are not very interested in death. The modern English and American analytic philosophers have even asserted that the limited study of death proves that this phenomenon cannot really be explored philosophically.

Two things explain their attitude: first, their war on metaphysics; and second, their belief that the social sciences and psychology can study death much better. At any rate, whenever philosophers did study death, they emphasized four basic issues:

1. The nature of death.

2. Knowledge of death.

3. Fear of death.

4. The social and psychological forces affecting our knowledge of death.

As for the first of these four issues, most religions have considered death, not as a natural occurrence, but as a consequence of a supernatural attack. Another prevalent attitude throughout history has been that birth control is much less important than death control (except for infanticide and child exposure, human sacrifice, cannibalism, capital punishment, and war). This explains why fertility rates are decreasing more slowly than mortality rates. Moreover, in high mortality societies death threatens the entire community, which results in wide cooperation aimed at the solution of problems generated by death. In low mortality cultures, however, death merely threatens the personality system, thus being a personal tragedy, namely, one involving relatives and friends. Consequently, bereavement assumes a tremendous variety of forms.

The complexity of thanatology is further indicated by varying definitions of the individual. In rural Puerto Rico, for example, the child is regarded as an incomplete person, sinless, pure, and innocent. This means that, after death, he joins the angels, which explains why children's funerals are joyful affairs. Among the Arapaho Indians, however, the child is considered similar to adults and, like them, departs to the land of the spirits after death. His burial, therefore, is an adult ritual during which his parents slash themselves and engage in other forms of exceedingly emotional behavior. Similarly, some societies have considered senilicide, or geronticide (the killing of the aged), perfectly acceptable. This may be accomplished through homicide or suicideeither forced or voluntary. The reasons for geronticide are at least five: 
1. Fear of an old person's superior knowledge, greater power, or higher social status.

2. The belief that he has already had a full life.

3. His limited economic productivity - he feels and is considered useless.

4. Social isolation of the elderly.

5. The subsistence level of a society's economy - the climate is severe, life is rather nomadic, and the supply of food is inadequate.

But the Murngin of Australia consider old age a status symbol, their age statification being characterized by elaborate rites of passage. The highest stratum consists of the oldest members of that society.

Death by suicide is also a highly complex phenomenon, as varying definitions suggest. In his Mohave Ethnopsychiatry and Suicide (1961), George Devereux indicates that the Mohave think of the following events as forms of suicide:

1. Actual suicides.

2. Funeral suicides.

3. Vicarious suicides.

4. Stillbirths.

5. Infant deaths after abrupt weaning because of a new pregnancy.

6. Death of one or both twins before marriage or in childbirth.

7. Symbolic suicides in incestuous unions.

A special type of suicide is the Samsonic form, which is based on revenge against an enemy.

As for burial, only man buries the dead. The earliest evidence reveals that hygiene was not the reason for this, but that a primitive philosophy of life and death led to funerary ritualism. Paleolithic man, for instance, buried the corpse together with food, tools, and ornaments, which means that an afterlife was part of this primitive philosophy. Even Neanderthal man (50,000 B.C.) had similar beliefs and customs.

\section{Definitions}

\section{Definition of death}

But what is death? Once more, the complexity of this subject is also revealed by our futile efforts to define it. A common definition is that death is the absence of life. This assertion, however, is exceedingly naive, since it is negative, namely, it tells us what death is not, not what it is. In general, since life has not always been explained naturalistically, death has often been described supernaturally. Some primitives, for instance, attribute it to gods or demons. Religion has referred to it as the departure of the soul from the body, or the destruction of the body-soul unity. More specifically, Christianity saw Adam's sin as the cause of death, while a modern philosopher, Martin Heidegger (Sein und Zeit, 1927), has averred that death is not a natural phenomenon.

In law, death has been defined in three main ways:

1. "Natural death" is "the cessation of life," or "the ceasing to exist," or a total stoppage of the circulation of the blood, and a cessation of the animal and vital functions consequent thereon, such as respiration, pulsation, etc. 
2. "Civil death" is the state of a person who, though possessing natural life, has lost all his civil rights, and as to them, is considered as dead.

3. "Violent death" is one caused or accelerated by the interference of human agency.

Another legal type, "presumptive death," refers to that which is presumed from proof of a long continued absence unheard from and unexplained, such absence usually lasting seven years.

From the physical point of view, there is a distinction between clinical death, which refers to the entire organism, and biological death, which covers individual organs. Since not all the components of the organism discontinue their function simultaneously and to the same extent, death has also been defined as a process. In other words, the line between life and death is always arbitrary, depending on our purpose and criteria.

Traditionally, clinical death has been regarded as the absence of the following: a heartbeat (therefore, lack of a peripheral pulse), breathing (thus, presence of bluing of the lips, mouth, and limbs), and certain eye reflexes. In addition, three other conditions make their appearance: algor mortis (the chill of death), rigor mortis (rigidity of skeletal muscles), and livor mortis (cutaneous purple-red spots on portions of the cadaver due to the settling of the blood). But most mammals have six essential parts, that is, the gastrointestinal, excretory, respiratory, circulatory, nervous, and supportive systems. And their damage does not lead equally to death. For instance, there is no death even when much of the bone is lost or if a kidney stops functioning for hours. But if the heart and lungs discontinue their function even for a few minutes, death may result. Now, however, this definition becomes inadequate, since clinical death may be prevented by means of pacemakers, respirators, and the like. In fact, this is even true of cases where the brain has stopped functioning, namely, when cerebral death has occurred.

Brain death, of course, which means cessation of the brain processes, presents an additional difficulty. This is the philosophical mind-body problem, one of the most controversial hypotheses dealing with it being the "identity thesis," namely, that brain processes and consciousness coincide.

Cellular death involves the cell, which, as is well known, lives only when growth, assimilation, and division occur. Nerve cells, however, are never replaced, and replacement does not present the same rate for all cells. Besides, it is exceedingly difficult to determine exactly when the homeostatic mechanism of the cell undergoes irreversible damage, that is, death. Then, the same kind and degree of damage is not equally destructive to all cells. Phosphorus, for example, affects the peripheral cells of the liver, and chloroform the central cells. Hypoxia (lack of an adequate amount of oxygen) does not damage all cells similarly. A cell may rupture (cytolysis), or its nucleus may shrink (pyknosis), fragment (karyorrhexis), or rupture (karyolysis). Finally, electronic microscopic inspection reveals cell damage quite early, whereas light microscopic inspection does so several hours later.

In general, cerebral and cardiorespiratory functions were considered interdependent in the past. Modern technology, however, has separated these functions, which now can continue independently. Of course, there are degrees of biological disintegration, some of the marginal states between life and death being artificial survival, coma vigil 
(delirious lethargy with open eyes and partial consciousness), coma depassé, persistent vegetative state, and irreversible coma. More specifically, a distinction has been made between cardiac death and brain death, the latter being subdivided by some authorities into cerebral death and cortical death. In brief, it seems more helpful to distinguish between cardiological and neurological criteria of death, while the traditional criteria have been of two types: three primary (respiration, cardiac pulse, and blood pressure) and one secondary (body temperature).

Finally, medical conferences during the late 1960's have stressed irreversible coma as a criterion of death. This refers to a permanently nonfunctioning brain, that is, a flat electroencephalographic recording, or absence of brain waves. These conferences have also emphasized a lack of spontaneous cephalic reflexes, muscular movements, and respiration. Later, the criterion of an agonal angiogram was added (diminished blood circulation). Unfortunately, these criteria are unsatisfactory in cases of hypothermia (body temperature below $32 \mathrm{C}$ ), or severe central nervous system depression due to a drug overdose. Besides, irreversibility cannot be determined objectively, for what was irreversible in the 19th century can now be reversed, and the 20th century's irreversible coma may be reversed in the 21 st century.

\section{Bereavement}

Bereavement is defined as the objective situation one faces after having lost an important person via death. Bereavement is conceptualized as the broadest of the three terms and a statement of the objective reality of a situation of loss via death.

Bereavement is the time period after a loss during which grief is experienced and mourning occurs. The time spent in a period of bereavement depends largely on how attached and dependent the person was to the person who died and how much time was spent anticipating the loss. Death is like pulling the band aid off the hairy part of your arm. You know it's gong to hurt. There's no sure way to escape the pain. For slow peelers to quick stripper it's still going to hurt.

\section{Mourning}

Mourning is defined as the public display of grief. While grief focuses more on the internal or intrapsychic experience of loss, mourning emphasizes the external or public expressions of grief. Consequently, mourning is influenced by one's beliefs, religious practices, and cultural context. There is obvious overlap between grief and mourning, with each influencing the other; it is often difficult to distinguish between the two. One's public expression (i.e., mourning) of the emotional distress over the loss of a loved one (i.e., grief) is influenced by culturally determined beliefs, mores, and values.

\section{Grief}

Grief is defined as the primarily emotional/affective process of reacting to the loss of a loved one through death. The focus is on the internal, intrapsychic process of the individual. Normal or common grief reactions may include components such as the following:

- Numbness and disbelief.

- Anxiety from the distress of separation.

- A process of mourning often accompanied by symptoms of depression.

- Eventual recovery. 
Grief reactions can also be viewed as abnormal, traumatic, pathologic, or complicated. Although no consensus has been reached, diagnostic criteria for complicated grief have been proposed.

\section{Attitudes towards death}

According to DeSpelder and Strickland (2006), by assessing our past experiences and projecting our imaginations into the future, we develop attitudes that prepare us to respond to the varied situations we encounter in life. Attitudes toward death reveal themselves through the language people use when talking about death and the humor they employ in response to it, as well as through the manner in which death is portrayed by the media and in music, literature, and the visual arts. Although direct, firsthand experience with death is rare for most people in modern societies, death still has a significant, even if rarely acknowledged, place in our social and cultural environment.

\section{Language}

When people talk about dying or death, they often use language that is indirect. The words dead or dying tend to be avoided; instead, loved ones "pass away" and the deceased is "laid to rest." Burial becomes "interment," and the undertaker is transformed into a "funeral director." Such language suggests a well-choreographed production surrounding the dead. A careful listener will notice that euphemisms, metaphors, and slang comprise a large part of "death talk" (see Table).

Euphemisms-substitutions of indirect or vague words and phrases for ones considered harsh or blunt-may be used to keep death at arm's length by masking its reality. In some cases, euphemisms are used to devalue and depersonalize death. This occurs, for example, when plain talk about death is subverted by a lexicon of substitutions -as when soldiers killed in battle are described in terms of "body counts" or civilian deaths are termed "collateral damage." When used in this way, euphemisms replace accurate descriptions of the horror of death in war.

It is important to recognize, however, that the use of euphemisms and metaphors does not always imply an impulse to deny death or avoid talking about it. Sometimes these linguistic devices communicate subtler or deeper meanings. Among members of some religious and ethnic traditions, for example, terms like "passing" convey an understanding of death as a spiritual transition.

In a similar manner, sympathy and condolence cards generally allow people to express their condolences to the bereaved without directly mentioning death. Death may be referred to metaphorically, as in sentiments like "What is death but a long sleep?" or apparently denied in verses like "He is not dead, he is just away." Images of sunsets and flowers are often used to create an impression of peace, quiet, and perhaps a return to nature. Bereavement, the fact of losing a loved one by death, may be mentioned within the context of memories or the healing process of time. Sympathy cards acknowledge loss in a gentle fashion intended to comfort the bereaved.

Language usage can also reveal something about the intensity and immediacy of a person's close encounter with death. In "danger of death" narratives-stories about close 
calls with death-a tense shift typically occurs when the narrator comes to the crucial point in his or her story, the point when death seems imminent and unavoidable. In one instance, a man who had experienced a frightening incident some years earlier while driving in a snow storm began his story in the past tense as he described the circumstances. But as he came to the point when his car went out of control on an icy curve and slid into the opposing lane of traffic, he switched to the present tense. It was as if he were reliving the experience of watching the oncoming car heading straight for him and believing in that moment that he was about to die.

Word choices also reflect changes in the way a death event is experienced at different times. For example, after the terrorist attack of September 11, 2001, when the focus of rescue efforts changed, so did the language used to describe the work of emergency personnel and search-and-rescue teams. As hours stretched into days, rescue work became recovery work.

Efforts to find words to adequately describe what happened on September 11 were evident in the days and weeks immediately following as people resorted to a variety of phrases such as "the terrorist attacks," "the events of Septem ber 11," "the tragedy," or simply "it." Each word choice has its own associations and connotations. For some people, the word "attack" was too vague; for others, "event" seemed to trivialize what occurred. Many police officers, firefighters, military personnel, and others who viewed the experience as a direct assault found the word "attack" to be an apt description that helped mobilize a response. Others preferred the word "tragedy" because it suggested a focus on emotional recovery, such as occurs after disasters. Another solution to the issue of word choice was what linguists call a metonym, a kind of shorthand way of referring to an event. Just as "Pearl Harbor" became a metonym for the Japanese attack on Hawaii in World War II, "September 11" or "9-11 " became a way of describing the sequence of events at the World Trade Center, at the Pentagon, and in Pennsylvania.

After trying out the words "attack," "tragedy," and "a bombing," one man said the name "September 11" had the most resonance because it was all of those things and more. People who experience the same death-related event from different perspectives may have different ways of talking about it. When Kurt Cobain of the rockgroup Nirvana died by suicide, the language used by fans and by the media showed interesting contrasts. Whereas fans expressed their shock by saying, "Can you believe it? He offed himself; he actually blew himself away," reporters used formal language to describe Cobain's death by "suicide" from "gunshot."

Look again at the words and phrases used in death talk (Table). Notice how language offers clues about the manner of death and a speaker's attitude toward the death. Consider, for instance, the differences between "passed away" and "passed on". Subtle distinctions can reflect very different attitudes, sometimes involving cultural or spiritual frameworks. Paying attention to the metaphors, euphemisms, slang, and other linguistic devices people use when talking about death helps us appreciate the variety and range of attitudes toward dying and death.

Table. Death Talk: Metaphors, Euphemisms, and Slang

\begin{tabular}{|l|l|}
\hline $\begin{array}{l}\text { Passed on } \\
\text { Croaked }\end{array}$ & $\begin{array}{l}\text { Made the change } \\
\text { Taking the dirt nap }\end{array}$ \\
\hline
\end{tabular}




\begin{tabular}{|l|l|}
\hline Kicked the bucket & On the other side \\
Gone to heaven & God took him/her \\
Expired & Asleep in Christ \\
Breathed the last & Departed \\
Succumbed & Trancended \\
Left us & Bought the farm \\
Went to his/her eternal reward & With the angels \\
Lost & Feeling no pain \\
Met his/her Maker & Offed himself/herself \\
Wasted & His/her time was up \\
Checked out & Cashed in \\
Eternal rest & Crossed over Jordan \\
Laid to rest & Perished \\
\hline
\end{tabular}

\section{Awareness of death}

Both Sheets-Johnstone and Foucault argue that awareness of death is at the root of thought and language. There is no way of escaping from this connection, even if we call upon thought and language to conceal death from us. Neither of these authors are psychologists per se; rather, they are philosophers with a broad range of historical, cultural, and scientific knowledge.

According to Kastenbaum (2000), "You are dead" and "I will die" are two concepts that might at first appear simple and self-evident, but are in fact very difficult.

\section{"You Are Dead"}

One of most fundamental distinctions occurs between our conceptions of the death of the other and the death of the self. The first of these constructions can be expressed as "You are dead." It is more concrete and therefore more within the young child's grasp to begin with "dead" rather than "death." "Hammy the Hamster is dead" literally makes more sense-especially when one is looking at or touching Hammy - than "Death has taken our beloved hamster as it must all mortal beings."

There is reason to believe that "You are dead" develops earlier and more rapidly than the inward-looking, "I will die." But the child must know, guess, or imagine several notso-simple concepts in order to arrive at the conclusion: "You are dead"?

\section{You are absent}

But what does it mean to be absent? We must appreciate the observer's frame of reference. For a young child, the frame of reference is largely perceptual. Absence means not hereand-now. The younger or less developed the child, the more that hereand-now are condensed into the same global unit. Spatial and temporal dimensions are not yet treated independently. Suppose that you are "away," in another city. From an adult frame of reference, you have a spatial existence at the present time, even though you are not within my own personal space. But the child experiences your total absence. You are not in the child's perceptual space at this moment, therefore, you are not. 


\section{I am abandoned}

This statement is the organismic reciprocal of the first proposition. Your disappearance from my perceptual frame of reference has destroyed my sense of security. As the child, I am not merely aware of your absence, but also of the presence of dysphoric feelings within myself. Your absence and my anxiety are intimately related. We see that the child has an organismic, embodied response. There is a cognitive core, but the stress and fear run through and through the child's state of being.

3. Your absence plus my sense of abandonment contributes to the general sense of separation.

I have been isolated from the contact and support that I need to feel safe in the world and good about myself. This separation may also lead me to experience a pervasive sense of having lost contact with the environment, not just with you.

I am nowhere. I am anxiety. Furthermore, my distress may have been intensified by the feeling that I was forcibly separated from you, wrenched away. This trauma could intensify the already bleak picture of absence and abandonment. Sheets-Johnstone (1990) maintains that this sense of sundering between the observer and the observed is crucial to forming the concept of death. She focuses on the perception of a dead person or animal, how different it is from the living version. In our view, this sense of alarming separation also has its roots in the infant and young child's awareness that the motherself bond has been violated.

4. The separation has no limits.

Young children do not grasp the concept of futurity nor of a general time that flows directionally through all lives everywhere. They live in a world of what might be called "local time" that is limited to its overall egocentric organization of experience. Therefore, the immediate experience of separation cannot be modulated by future expectations. The infant or young child cannot say to itself, "Mother has gone away... but she will return Wednesday and have a nice present for me." The young child cannot distinguish among short-term, long-term, and final, irreversible separations.

Once the separation experience has been induced, the child has no dependable way of estimating or anticipating its conclusion. What the outsider may regard as a brief separation may be indistinguishable in the child's mind from the prospect of prolonged separation. Is not-here-now the same as never-again? Even very young children experience the former; it is more difficult to determine just when they start to comprehend the latter.

5. The child's involvement in recurring psychobiological rhythms complicates its relationship to separation and death.

You and I have accepted the existence of "objective" or "external" time that moves unit by standard unit from the past, through the present, to the future: a clockwork universe that does not much care about our own wishes and priorities. It is different for the child whose time begins afresh each morning when he/she awakens. Midday nap signals a "time-out." The child's experience of time is strongly influenced by its internal rhythms of hunger-satiation, sleep-activation, and so forth, as well as the recurring rhythms of night and day. 
How does this relationship to time affect the child's construction of death-of-the-other? The vulnerability to separation has already been emphasized. For example, the child cannot distinguish well between the prospects of brief and extended or final separation.

Now we must give more attention to an apparent contradiction within the child's experiential world. The sense of limitless separation and the endlessness of any experience conflicts with the recurring rhythms, the periodicity that characterizes infancy and early childhood. As a child who feels abandoned, I have no way of establishing a future limit upon my present experience. The intensity of my distress suggests that I fear that this will go on and on without relief.

Nevertheless-and this is the more difficult part to grasp-my psychobiological state is always in transition. I am always becoming hungry or sleepy or curious or... something! And the environment in which I am embedded is also in transition. The sun is coming up or it is going down. Various periodic household routines are being started or completed. If the cat has just jumped on the ledge of the living room window, this means that the sound of Daddy's or Mommy's car will soon be heard; those rattling sounds in the kitchen suggest that food is again on the way, and so forth. As a cyclical creature in a cyclical environment, I do not maintain a constant frame of reference over a protracted period of clock or calendar time. There are breaks and interruptions in even my most steadfast thought and behavior patterns. In other words, I do not have a continuous experience. Periodic changes in my inner state and in my relationship with the external environment rest, refresh, and distract me. This means that my experiential world is subject to both rules:

(a) the lack of limits or boundaries within which to place a separation experience, but also

(b) the inability to maintain a steady frame of reference over an extended period of time.

As a young child I might misinterpret your temporary departure as being a consequential separation. By this same token, however, I may under estimate a consequential separation-even your death. My cyclical pattern of functioning has lead me to anticipate that every end has a fresh beginning, just as every beginning has an end. But there is no end to ends. You have been away a long time now. I measure "long time" arbitrarily by my own feelings-long enough to make me feel uncomfortable, abandoned. And I have deeply rooted within me the expectation that the familiar pattern of separationreunion will be repeated. Two opposite responses can testify to the young child's special relationship to time:

(a) The child may respond in panic or despair over what is objectively a brief and insignificant separation because to the child this feels like total and unmoderated abandonment or

(b) the child may respond as though expecting a dead parent, sibling, or animal companion to return any minute now.

\section{You do not respond.}

This applies to the specific situation in which an infant or young child is in close contact with a dead person or animal. It can also involve a "dead toy" that does not do what it was supposed to do. The most characteristic behavior I have observed in this kind of situation involves the child's attempt to persuade the dead other to respond. 
Nonresponsiveness, of course, remains an important constituent of the death construct for adults as well. This includes death in the literal sense: "The eyes did not respond to light; there was no response to pressure or pain stimuli, or to words." It also includes death in the figurative sense: "Alas, Percy was dead to my pleas."

For the young child, it is clear that the concept of nonresponsiveness arises from an interactive context. "I will make you move. I will make you talk to me. I will make you smile." It is only through the expectation of responsiveness and through failed attempts to elicit responsiveness that the child can generate this facet of the "You are dead" concept. Very early in development, then, an infant or young child will have considerable difficulty in grasping the concept of nonresponsivity. Experience with the world as well as maturational changes in the central nervous system will soon teach the child that it is characteristic of living things to respond, and, therefore, a

discomfirmation of expectation when they do not. But precisely what-and how-are children thinking when they puzzle over a nonresponsive being or toy? There is an emerging controversy here that we will take up when we review empirical studies on the child's constructions of death.

For children as well as adults it is much easier to realize death when one has had the evidence of one's own senses to support this conclusion. Again, this is an embodied response: one feels as well as thinks. The need to realize death is perhaps the most frequently cited reason for advocating open caskets at memorial services: there really is a body in that casket, and it is the body of our deceased friend. The young child's direct experience of a dead person or animal will differ appreciably from an adult's, but in either instance this kind of contact does provide a firmer reality base for one's response. A 2-year-old does not think of death the way his/her parents do, but the encounter with a cold, still, unresponsive form conveys vital, if still mysterious information.

\section{"I Will Die"}

This proposition requires even more of the child. We are not in a position to make this statement in a meaningful way until we have mastered a number of related concepts. These include the following:

1. I am a person with a life of my own, a personal existence.

2. I belong to a class of beings, one of whose attributes is mortality.

3. Using the intellectual process of logical deduction, I conclude that my personal death is a certainty.

4. There are many possible causes of my death, and these causes might operate in many different combinations.

5. Although I might overcome or evade one particular cause, I cannot overcome or evade all causes.

6. My death will occur in the future. By future, I mean a time-to live that has not yet elapsed, a time that I have not previously experienced.

7. But I do not know when in the future my death will occur. The event is certain; the timing is uncertain.

8. Death is a final event. My life ceases. This means that I will never again experience, think, or act, at least as human being on this earth.

9. Accordingly, death is the ultimate separation of myself from the world. 
"I will die" implies self-awareness, logical thought operations, conceptions of probability, necessity, and causation, of personal and physical time, of finality and separation. It also requires bridging a tremendous gap: from what I have actually experienced of life to a construction of life's negation. I have not been dead (the state). I have not experienced death (the event). Therefore, the mental operations that I call upon in my efforts to fathom death tend to falsify as they proceed. If death implies lack of movement, then my eyes conspire against this fixed image by moving restlessly as I scan the environment (your eyes do the same). If death implies emptiness or silence, my mind again rushes ahead to fill in the void with its own operations, just as people in sensory deprivation experiments manufacture their own stimuli to satisfy our need for cognitive activity. Our mind's own modus operandi equips us for interpreting life, not life's negation. This will continue to be a problem for adults, and probably contributes to the child's difficulties in comprehending cessation of life.

Brock Haussamen (1998) argues that the rules of our language systematically falsify the propositions we articulate about death. More specifically, our syntax often produces a denial rather than an acknowledgment of death. Language does not have much respect for the dead, in the sense that it does not treat them any differently than it does the living. Some of the ways we refer to the dead-not euphemisms but the most ordinary statements-are incongruous, on the fact of it. The verb in the sentence John is dead, for instance, is in the present tense, as if the statement were a variation on John is sick. And the other ordinary announcement of death-John died-has the same structure as any other in which John did something intransitive, such as John fell or John slept. John may have died, but in saying so we present him as the same source of action that he always was.

Simple sentences about a person's death cannot help but cast the person in the mold of the living, The more rapidly children master language, then, perhaps the more rapidly they learn to present their discoveries about death in a way that subtly contradicts their insights into the fundamental disconnect between being and nonbeing. Perhaps, as Foucault suggests, the very act of speaking or writing about death achieves a triumphant denial:

Death is undoubtedly the most essential of the accidents of language (its limits and its center): from the day that men began to speak toward death and against it, in order to grasp and imprison it, something was born, a murmuring which repeats, recounts, and redoubles itself endlessly, which has undergone an uncanny process of amplification and thickening, in which our language is today lodged and hidden. To put it another way: the dead are not dead if we can retain and revive them through words, and we will not die as long as we are speaking, listening, writing, or reading. Again, Foucault: " . . discourse has the power to arrest the flight of an arrow".

Children, through their avid observations and compelling discoveries, are less likely than adults to thicken and hide their constructions of death. Improving our understanding of the child's growing awareness of death may be essential to understanding how we manipulate these ideas as adults.

There is a further difficulty as well. Children's conceptions of death often are influenced by encounters with a dead person, animal, or plant. Yet these perceptions do not truly 
bridge the gap. The deadness is perceived from the outside only. What it feels like not to feel eludes me. In the language of phenemonology, the Otherness of the dead startles us into awareness of the chilling distance between life and death. However, under some circumstance both children and adults are vulnerable to misinterpretations, taking the living for dead, or vice versa. Experiences with the dead and with the transition from alive to dead must be taken into account as we attempt to understand the development of death conceptions.

\section{Death anxiety}

A generalized expectation of danger occurs during the stressful condition known as anxiety. The anxious person experiences a state of heightened tension that Walter Cannon described in 1927 as readiness for "fight or flight." If the threat passes or is overcome, the person (or animal) returns to normal functioning. Anxiety has therefore served its purpose in alerting the person to a possible danger. Unfortunately, sometimes the alarm keeps ringing; the individual continues to behave as though in constant danger. Such prolonged stress can disrupt the person's life, distort relationships, and even produce life-threatening physical changes. Is the prospect of death the alarm that never stops ringing? Is death anxiety the source of people's most profound uneasiness? Or is death anxiety a situational or abnormal reaction that occurs when coping skills are overwhelmed?

There are numerous examples of things that people fear-cemeteries, flying, public speaking, being in a crowd, being alone, being buried alive, among others. Unlike anxiety, a fear is associated with a more specific threat. A fear is therefore less likely to disrupt a person's everyday life, and one can either learn to avoid the uncomfortable situations or learn how to relax and master them. Fears that are unreasonable and out of proportion to the actual danger are called phobias. Many fears and phobias seem to have little or nothing to do with death, but some do, such as fear of flying or of being buried alive.

\section{Theories of Death Anxiety and Fear}

Two influential theories dominated thinking about death anxiety and fear until the late twentieth century. Sigmund Freud (1856-1939) had the first say. The founder of psychoanalysis recognized that people sometimes did express fears of death. Nevertheless, thanatophobia, as he called it, was merely a disguise for a deeper source of concern. It was not death that people feared because:

Our own death is indeed quite unimaginable, and whenever we make the attempt to imagine it we.... really survive as spectators... At bottom nobody believes in his own death, or to put the same thing in a different way, in the unconscious every one of us is convinced of his own immortality.

The unconscious does not deal with the passage of time nor with negations. That one's life could and would end just does not compute. Furthermore, whatever one fears cannot be death because one has never died. People who express death-related fears, then, actually are trying to deal with unresolved childhood conflicts that they cannot bring themselves to acknowledge and discuss openly. 
Freud's reduction of death concern to a neurotic cover-up did not receive a strong challenge until Ernest Becker's 1973 book, The Denial of Death. Becker's existential view turned death anxiety theory on its head. Not only is death anxiety real, but it is people's most profound source of concern. This anxiety is so intense that it generates many if not all of the specific fears and phobias people experience in everyday life. Fears of being alone or in a confined space, for example, are fears whose connections with death anxiety are relatively easy to trace, but so are the needs for bright lights and noise. It is more comfortable, more in keeping with one's self-image, to transform the underlying anxiety into a variety of smaller aversions.

According to Becker, much of people's daily behavior consists of attempts to deny death and thereby keep their basic anxiety under control. People would have a difficult time controlling their anxiety, though, if alarming realities continued to intrude and if they were exposed to brutal reminders of their vulnerability. Becker also suggested that this is where society plays its role. No function of society is more crucial than its strengthening of individual defenses against death anxiety. Becker's analysis of society convinced him that many beliefs and practices are in the service of death denial, that is, reducing the experience of anxiety. Funeral homes with their flowers and homilies, and the medical system with its evasions, are only among the more obvious societal elements that join with individuals to maintain the fiction that there is nothing to fear.

Ritualistic behavior on the part of both individuals and social institutions generally has the underlying purpose of channeling and finding employment for what otherwise would surface as disorganizing death anxiety. Schizophrenics suffer as they do because their fragile defenses fail to protect them against the terror of annihilation. "Normal" people in a "normal" society function more competently in everyday life because they have succeeded at least temporarily in denying death.

Other approaches to understanding death anxiety and fear were introduced in the late twentieth century. Terror management theory is based on studies finding that people who felt better about themselves also reported having less death-related anxiety. These data immediately suggested possibilities for preventing or reducing disturbingly high levels of death anxiety: Help people to develop strong self-esteem and they are less likely to be disabled by death anxiety. If self-esteem serves as a buffer against anxiety, might not society also be serving this function just as Becker had suggested? People seem to derive protection against death anxiety from worldview faith as well as from their own self-esteem. "Worldview faith" can be understood as religious belief or some other conviction that human life is meaningful, as well as general confidence that society is just and caring.

Another fresh approach, regret theory, was proposed in 1996 by Adrian Tomer and Grafton Eliason. Regret theory focuses on the way in which people evaluate the quality or worth of their lives. The prospect of death is likely to make people more anxious if they feel that they have not and cannot accomplish something good in life. People might torment themselves with regrets over past failures and missed opportunities or with thoughts of future accomplishments and experiences that will not be possible. Regret theory (similar in some respects to Robert Butler's life review approach) also has implications for anxiety reduction. People can reconsider their memories and 
expectations, for example, and also discover how to live more fully in the present moment.

Robert Kastenbaum suggests that people might not need a special theory for death anxiety and fear. Instead, they can make use of mainstream research in the field of life span development. Anxiety may have roots in people's physical being, but it is through personal experiences and social encounters that they learn what might harm them and, therefore, what they should fear. These fears also bear the marks of sociohistorical circumstances. For example, fear of the dead was salient in many preliterate societies throughout the world, while fear of being buried alive became widespread in nineteenth-century Europe and America. In modern times many people express the somewhat related fear of being sustained in a persistent vegetative state between life and death. Death-related fears, then, develop within particular social contexts and particular individual experiences. People do not have to rely upon the untested and perhaps untestable opposing views of Freud and Becker - that they are either incapable of experiencing death anxiety, or that death anxiety is the source of all fears. It is more useful to observe how their fears as well as their joys and enthusiasms are influenced by the interaction between cognitive development and social learning experiences. In this way people will be in a better position to help the next generation learn to identify actual threats to their lives while not overreacting to all possible alarms all the time.

\section{Death Anxiety Studies}

According to Kastenbaum (2010), there have been many empirical studies of death anxiety, but many questions also remain because of methodological limitations and the difficulties inherent in this subject. Nevertheless, a critical review of the literature does reveal some interesting patterns:

- Most people report that they have a low to moderate level of death-related anxiety.

- Women tend to report somewhat higher levels of death-related anxiety.

- There is no consistent increase in death anxiety with advancing adult age. If anything, older people in general seem to have less death anxiety.

- People with mental and emotional disorders tend to have a higher level of death anxiety than the general population.

- Death anxiety can spike temporarily to a higher level for people who have been exposed to traumatic situations.

Religion. The relationship between death anxiety and religious belief seems to be too complex to provide a simple pattern of findings. Death-related teachings differ, and believers may take different messages from the same basic doctrine. Historical studies also suggest that religious faith and practices seem to have sometimes reduced and sometimes increased death anxiety.

Health. The findings already mentioned come mostly from studies in which respondents in relatively good health reported on their own fears. Other studies and observations, though, give occasion for further reflection. There is evidence to suggest that people may be experiencing more anxiety than they are able to report. Even people who respond calmly to death-related words or images show agitation in breathing, heart rate, and reaction time, among other measures. Researchers Herman Feifel and B. Allen 
Branscomb therefore concluded in 1973 that everybody, in one way or another, is afraid of death. Presumably, people may have enough self-control to resist death-related anxiety on a conscious level but not necessarily to quell their underlying feelings of threat.

Gender. The gender differences also require a second look. Although women tend to report higher levels of death-related anxiety, it is also women who provide most of the professional and volunteer services to terminally ill people and their families, and, again, it is mostly women who enroll in death education courses. Women are more open to death-related thoughts and feelings, and men are somewhat more concerned about keeping these thoughts and feelings in check. The relatively higher level of reported death anxiety among women perhaps contributes to empathy with dying and grieving people and the desire to help them cope with their ordeals.

Age. The relationship between age and death anxiety is also rather complex.

Adolescents may at the same time harbor a sense of immortality and experience a sense of vulnerability and incipient terror, but also enjoy transforming death-related anxiety into risky death-defying activities. What people fear most about death often changes with age. Young adults are often mostly concerned about dying too soon-before they have had the chance to do and experience all they have hoped for in life. Adult parents are often more likely to worry about the effect of their possible deaths upon other family members. Elderly adults often express concern about living "too long" and therefore becoming a burden on others and useless to themselves. Furthermore, the fear of dying alone or among strangers is often more intense than the fear of life coming to an end. Knowing a person's general level of anxiety, then, does not necessarily identify what it is that most disturbs a person about the prospect of death.

Anxiety levels. The fact that most people report themselves as having a low to moderate level of death anxiety does not offer support for either Freud's psychoanalytic or Becker's existential theory. Respondents do not seem to be in the grips of intense anxiety, but neither do they deny having any death-related fears. Kastenbaum's Edge theory offers a different way of looking at this finding. According to the theory, most people do not have a need to go through life either denying the reality of death or in a high state of alarm. Either of these extremes would actually interfere with one's ability both to enjoy life and cope with the possibility of danger. The everyday baseline of low to moderate anxiety keeps people alert enough to scan for potential threats to their own lives or the lives of other people. At the perceived moment of danger, people feel themselves to be on the edge between life and death, an instant away from catastrophe. The anxiety surge is part of a person's emergency response and takes priority over whatever else the person may have been doing. People are therefore not "in denial" when, in safe circumstances, they report themselves to have a low level of death anxiety. The anxiety switches on when their vigilance tells them that a life is on the edge of annihilation.

\section{Anxiety and Comfort Near the End of Life}

What of anxiety when people are nearing the end of their lives, when death is no longer a distant prospect? The emergence of hospice programs and the palliative care movement is stimulating increased attention to the emotional, social, and spiritual needs of dying people. Signs of anxiety are more likely to be recognized and measures 
taken to help the patient feel at ease. These signs include trembling, restlessness, sweating, rapid heartbeat, difficulty sleeping, and irritability. Health care professionals can reduce the anxiety of terminally ill people by providing accurate and reassuring information using relaxation techniques, and making use of anxiolytics or antidepressants.

Reducing the anxiety of terminally ill people requires more than technical expertise on the part of physicians and nurses. They must also face the challenge of coping with their own anxieties so that their interactions with patients and family provide comfort rather than another source of stress. Family and friends can help to relieve anxiety (including their own) by communicating well with the terminally ill person.

\section{Coping behaviors}

1. Creativity: An immersion in creative work - art, music, writing - is in itself an obsession that crowds out death-related obsession. You "live through your creations," and in rare cases achieve a kind of immortality or the illusion of immortality.

2. Love: Caring for others, especially for the stranger, lifts the individual out of himself and his fears. The reciprocation of that love by others in his family, his friends, lovers, and others offers strong emotional support and diminishes death fear.

3. Humor: This is one of the bulwarks against the threat of death. It is not the type of humor that denigrates others, but the "laughing at fate" that is life-enhancing and perhaps life-prolonging.

4. Intellectualization: Writing about death and/or examining philosophical "secrets" that cannot really be revealed (such as what happens after death). By studying a threatening subject, such as death, one distances oneself from it. It is a very effective coping mechanism. Its downside is that, if the "distancing" becomes too great, intellectualization often becomes an escape from reality.

5. Procreation: Having children is one way of living on. It should involve love and respect for the children as individuals in their own right, not as little clones of narcissistic parents.

6. Obsessive-compulsive behavior: Striving for worldly success, the Protestant Ethic, originally linked to religion and a "state of grace," now focuses on health, productivity, success, wellroundedness, etc.

7. "Living life to the hilt" - Living better, living longer: Living life to the hilt can be a healthy response to the finitude of life, but when exaggerated it becomes an anodyne, keeping the feelings of deadness away. An example is the (often drunken) orgy of the soldier at his "Port of Embarkation." It is a last fling before possible death. In the movie "The Last Detail" (1973) with Jack Nicholson, a young sailor being transported to the brig (prison) is given a "night on the town" before incarceration. It is shown as a great kindness on the part of the arresting sailors.

Bachelor parties are a similar "last fling" in the eyes of the macho groom and his buddies, who see marriage as the end (death?) of his single life and his "freedom."

Perhaps "living life fully" could be contrasted with "living life to the hilt." The first could be considered in the normal range, the second pathological. However, we know there have been entire social movements and philosophies that embraced these lifestylesfor example, the Apollonian versus the Dionysian ("Eat, drink, and be merry, for tomorrow we die") cultures and the Greek cults. 
Living life longer than others (if not in better health) is often a source of pride for the elderly. To live beyond those in one's age cohort gives a brief sense of immortality. Living better than others or better than you lived originally (or better than your parents lived) is part of the American Dream. It has its roots in the Protestant Ethic. If you could accumulate more worldly goods (which proved you had worked hard) your chances of achieving a state of grace and entering heaven were considerably improved. Max Weber called this "worldly asceticism." Thorstein Veblen carried this idea further, showing that "conspicuous consumption" was a way of gaining stature in our society. The more wasteful the behavior, the greater the status. We have developed a "potlatch" behavior that puts the Kwakiutl ceremony of burning their possessions to shame. With the advent of the "communications highway" we are able to order things simply by touching the object when it appears on the computer screen! All of this consumption has put possessions (especially electronic gadgets ) between us and death. It is obsessive behavior of a special kind.

8. Group membership: Becker (1973) refers to sources of meaning for the individual. Belonging to a group - the family, state, nation, club, university, sports team (or identifying with some larger group as a "reference group," even though one is not a member) can be a strong bulwark against fear of dying.

9. Religion: Belief in the afterlife is a form of denial, but it is one of the most effective ways of diminishing the fear of death. The belief in metamorphosis is very widespread, and also effective. Religion is also a major rallying point for war and killing, a definite minus. Many people have said that "Fear created the Gods," but fear also created the belief in the afterlife, an effective bulwark against fear for much of the world's population.

10. Mementos and Monuments: The family photo album, an autobiography, memoirs and diaries, pyramids, endowed chairs, charitable trusts and wills are all ways of extending one's life, and one's control, beyond the grave. These range from the very humble to the most grandiose methods of coping with the fear of death.

11. Counterphobic behavior: Dangerous sports are one way of saying "I can't die" although they often do end in death. Hang-gliding, scuba-diving, boxing, rock and mountain climbing, surfing, acrobatics, and contact sports all involve great risk of injury and death. The counterphobe may think, "If I live through this, it will prove I'm immortal."

12. Gambling: This is usually considered to be another form of obsessive-compulsive behavior. It has the quality of a defiance of fate. Although it may be self-destructive in the long run, in the short term it preserves hope.

13. Dissociation: Some seek oblivion because their fear of death, or a living death, is so overwhelming. Initially drugs (including alcohol) are used to obtain a "high," which brings the semblance of enjoyment and good living. It is a bromide that drug use becomes a withdrawal from life. Schizoid thinking is another way of dealing with early threats to life.

Dissociation exhibits a continuum of severity, ranging from multiple personality (or identity) disorder through milder forms such as meditation and daydreaming. In its milder forms it can be an excellent adaptation.

14. Repression/denial: Repression and denial are closely related terms. Repression is defined (psychoanalytically) as "the rejection from consciousness of painful or disagreeable ideas, memories, feelings or impulses". Denial is defined (psychologically) as "an unconscious defense mechanism used to reduce anxiety by denying thoughts, feelings, or facts that are consciously intolerable." These terms seem 
applicable to adults, since they presumably already have rather well-formed ideas about death. Children, however, up to about age ten, do not have realistic ideas about death, so that they cannot be said to be in denial or to be repressing ideas about death in the same way that adults do. (Adolescents, and some adults, who have committed suicide have been shown to have had very immature ideas about death, and gave clues, such as leaving notes for the delivery man for the following day.)

In Denial of Death, Becker discusses the "disappearance" of the fear of death. He extensively quotes Gregory Zilboorg and Charles W. Wahl, both of whom use the term "repression." Denial (or repression) is seen as a mechanism necessary for psychological survival- as an escape from the "terror" of death. "Repression takes care of the complex symbol of death for most people" (Becker 1973).

15. Suicide: While there are many types of suicide [see Durkheim's anomic suicide (Durkheim, 1973) and the altruistic suicide, such as Hara-Kiri, the Kamikaze pilot, or the suicide of the professional soldier who has failed], the majority of Western suicides are a way of preempting death. They say, in effect, "You can't fire (kill) me, I quit!" Suicide can also be viewed as a solution to a seemingly insoluble problem. Paradoxically, it can also be viewed as an escape from death - a living death - which is an intolerable situation, usually caused by a major loss in work, love, or status which is "resolved' by the suicide.

16. Projection, killing, and the problem of evil: A paranoid individual has fears of all kinds, but he is terrified of being attacked by others. (It may be that the early linkage of paranoid schizophrenia to homosexuality in psychoanalytic thinking was the result of the extremely repressive behavior of society toward homosexuals. Although this has not improved $100 \%$, as the difficulty of the previous administration in persuading the armed forces to accept homosexuals attests, the content of paranoia may be changing as a result of social changes.)

The projection of his own aggressive and sexual impulses onto various religious and ethnic groups is a hallmark of the paranoid personality and the more severe forms of this disorder. If one fears being killed, one may seek a potential killer to fear. Similarly, if one wants to kill, then that wish must be projected upon others to protect the self.

Killing: Homicide and the killing of animals is another form of the mechanism of denial. Becker (1973), in his classic book, shows that people who kill others gain a perception of control over life and death. In so doing, they achieve a kind of illusory immortality.

\section{Bereavement}

According to Ann Dent (2005), although Sigmund Freud pioneered the study of mourning, it is only in the last 30 years or so that bereavement research has gained any real prominence. Researchers have now given us several new models and insights to guide and help the bereaved. But why do we need models? After all, people have been bereaved since human life began and have generally recovered without the help of any model of grieving.

We now recognise that grief reactions can have physical, emotional, cognitive, behavioural, sexual and spiritual components, varying in length and disruptiveness. Adequate and appropriate support may alleviate the probability of future ill-health and complications. This is not to say that all bereaved people will need help, nor that 
grief should be pathologised. However, when professionals are involved in supporting the bereaved, they need a knowledge base from which to practise and scientific knowledge provides a particularly solid base. Personal experience and intuition are important but they have two major limitations as a basis of understanding: first, a practitioner's experience may be too restricted to make valid generalisations about new situations, and second, personal experiences may be coloured by subjective values and prejudices.

\section{Stages and phases}

John Bowlby's theory on attachment (19611) would seem to underpin the basis for understanding bereavement. Bowlby provides an explanation for the common human tendency to develop strong affectional bonds. He views attachment as a reciprocal relationship that occurs as a result of long-term interactions, starting in infancy between a child and its caregivers. He suggests that grief is an instinctive universal response to separation.

Both Bowlby (1962) and Parkes (1973) suggest that grief is a predictable orderly pattern of responses to a death. Parkes suggests that grieving is a process, a sequence of reactions to the death of a significant loved one. The initial shock, resulting in umbness, can last for days, especially when a death is sudden, leading on to intense grief. Physical symptoms such as tightness in the chest, shortness of breath, loss of appetite and insomnia are common. Lack of concentration and restlessness may also be experienced, as well as feelings of isolation and loneliness. Interspersed with these reactions may be feelings of anger, guilt and fear. Anger may focus on different areas, depending on a person's circumstances; guilt is frequently associated with „,if only I had... or "if only I hadn' $t$ ". The expression and acknowledgement of anger and guilt may bring some relief, as may reassurance that these are "normal" reactions. When such feelings are suppressed, the bereaved person may exhibit signs of constant irritation and/ or physical tension. Fear can manifest itself as insecurity, a desire to escape from reality, and anxiety over apparent trivialities, leading sometimes to panic attacks in which the anxiety and fear are overwhelming and disrupt normal living.

\section{Tasks for the bereaved}

William J Worden in the 1980s formulated a slightly different model of grieving to those of Bowlby and Parkes. Describing grief as a process and not a state, Worden suggested that people need to work through their reactions in order to make a complete adjustment. In Worden's tasks of bereavement, grief is considered to consist of four overlapping tasks, requiring the bereaved person to work through the emotional pain of their loss while at the same time adjusting to changes in their circumstances, roles, status and identity. The tasks are complete when the bereaved person has integrated the loss into their life and let go of emotional attachments to the deceased, allowing them to invest in the present and the future.

\section{Dual process model}

A more recent and significant advance in our understanding of grief work is the dual process model developed by Stroebe and Schut $(1995,1996)$. They suggested that avoiding grief may be both helpful and detrimental, depending on the circumstances. While previous models centred on loss, the dual process model recognises that both expressing and controlling feelings are important - and it introduces a new concept, that 
of oscillation between coping behaviours. Grief is viewed as a dynamic process in which there is an alternation between focusing on the loss of the person who has died (loss orientation) and avoiding that focus (restoration orientation). The loss orientation encompasses grief work, while the restoration orientation involves dealing with secondary losses as a result of the death. For instance, an older widow may have to deal with finances, and house maintenance, which previously her husband dealt with.

Both the loss orientation and the restoration orientation are necessary for future adjustment, but the degree and emphasis on each approach will depend on the circumstances of the death, personality, gender and cultural background of each person. The model also posits that by taking time off from the pain of grief, which can be overwhelming, a bereaved person may be more able to cope with their daily life and the secondary changes to it.

\section{Continuing bonds}

A further important development in grief theory has been provided by the work of Klass et al (1997), who challenged conventional thinking that the purpose of grieving was the reconstitution of an autonomous individual who could leave the deceased behind and form new attachments, in other words, „break the bonds“ with the deceased. Klass and his colleagues suggest that the purpose of grieving is instead to maintain a continuing bond with the deceased, compatible with other, new and continuing relationships.

\section{Families making sense of death}

Most models of grief deal with the grief of individuals. Frequently, however, death affects a whole family, in which family members, including children, can influence and be influenced by others, and in which the death may mean different things to each. In many cases, the family is very often the prime provider of socialisation, social control and support. Certain factors either inhibit or enhance a family's grief. Families in which there are fragile relationships, secrets and divergent beliefs may have more difficulty in adjusting; whereas families who have frequent contact, rituals and a willingness for each member to share their feelings, may find it easier.

In summary, most models of grief suggest that the bereaved need to engage with their loss and work through it, so that life can be reordered and meaningful again. Most practitioners will be familiar with the stage/phase theories in identifying cognitive, social and emotional factors. Worden's tasks of bereavement give a framework to guide the bereaved in their grief work, while the dual process model demonstrates the need to deal with secondary stresses as well as the primary loss, with time away from both. It is also important to recognise that the bereaved do not need to forget and leave the deceased behind, but can integrate them into their future lives by means of a continuing bond.

While most research has focused on the individual, understanding the family dynamic is often of great importance for counsellors in identifying possible tensions between members and assessing how members may influence or be influenced by others, as well as understanding what the death means to each member. Each bereaved person is unique and will deal with a significant death in their own way; therefore there is no one right or wrong way to grieve. The challenge that faces practitioners each time we meet a bereaved person is to find what helps them best. No single model of grieving is 
recommended above the rest, as all have various components that may be helpful. Regardless of which model is used, the most important part of supporting a bereaved person lies in being with' them, listening intently to their story, acknowledging their feelings and guiding them to work towards a new, different and meaningful life without the deceased.

\section{References}

Bardis, Panos D. 1981 History of thanatology : philosophical, religious, psychological, and sociological ideas concerning death, from primitive times to the present. University Press of America, Washington, D.C.

Dent A. 2005. Supporting the bereaved: theory and practice. Counselling at Work. Autumn 2005.

DeSpelder LA., Strickland AL. 2006. The Last Dance: Encountering Death and Dying. Kastenbaum R. 2000. The Psychology of Death. Springer Publishing Company.

Kastenbaum R. Grief. Encyclopedia of Death and Dying. http://www.deathreference.com/Gi-Ho/Grief.html, last visited 23.11.10.

Kastenbaum R. Fear of death. Encyclopedia of Death and Dying. http://www.deathreference.com/A-Bi/Anxiety-and-Fear.html, last visited 23.11.10. Langner, Thomas S. 2002. Choices for Living : Coping with Fear of Dying. Hingham, MA, USA: Kluwer Academic Publishers.

Rando TA. Mourning. Encyclopedia of Death and Dying. http://www.deathreference.com/Me-Nu/Mourning.html, last visited 23.11.10. 